\title{
The Influence of Authentic Leadership on the Performance of Tasks
}

\author{
Farah Putri Wenang Lusianingrum \\ Faculty of Economics and Business, \\ Universitas Gadjah Mada, Indonesia
}

\author{
Claudius Budi Santoso \\ Faculty of Economics and Business, \\ Universitas Gadjah Mada, Indonesia
}

Received: Jan. 15, 2022 Accepted: Feb. 15, 2022 Online published: Feb. 16, 2022

doi:10.5296/ijhrs.v12i1.19472ＵRL: https://doi.org/10.5296/ijhrs.v12i1.19472

\begin{abstract}
This study aims to examine the overall mechanism of the role played by authentic leadership in influencing employee job performance by using a social cognitive theory approach. This study takes the initiative by examining a more progressive role of authentic leadership on employee performance through positive attitudes and contextual factors. To test this comprehensive process, this study uses multivariate SEM analysis and 357 respondents who are civil servants. The results show that: (1) authentic leadership has a positive effect on trust in leaders; (2) trust in the leadership has a positive effect on work engagement; (3) work engagement has a positive effect on task performance; (4) co-workers' support moderates the effect of work engagement on task performance. This research contributes to the testing of the integrative mechanism of the role of authentic leadership plays in employee performance and the enrichment of the context of role of the authentic leadership in the government organizational environment.
\end{abstract}

Keywords: authentic leadership, trust in the leader, work engagement, task performance, and support from colleagues

\section{Introduction}

Currently, empirical studies continue to expand upon positive leadership styles that emphasize the ethical and moral behavior of leaders (Arda et al., 2016). Leaders are no longer only required to be able to motivate employees, but also to behave ethically and morally. One 
form of this positive leadership style is authentic leadership. The concepts of authenticity, integrity, morality, and honesty underlie the formation of the authentic leadership construct (Avolio et al., 2004).

Furthermore, thus far, empirical research on authentic leadership has focused on outcomes in the form of positive employee attitudes which include commitment (Abid et al., 2012; Guerrero et al., 2014), satisfaction (Azanza et al., 2013; Cerne and Penger, 2014), work engagement (Bamford et al., 2013; Cerne and Penger, 2014), emotional intelligence, (Miao et al., 2018;), and proactive behavior (Cai et al. (2019)

Meanwhile, Banks et al. (2016) state that authentic leadership — and being exemplary-have been considered the key factor in mobilizing employee strengths to provide good performance of tasks. Task performance has a high relevance to the effectiveness of leadership style and contributes directly to the achievement of organizational goals (Peterson et al., 2012; Wang et al., 2014), so it is important it is considered as an outcome in authentic leadership research (Hoch et al., 2016).

A number of previous studies in the literature have examined the direct influence of authentic leadership behavior on task performance (Leroy et al., 2012; Peterson et al., 2012; Wong and Laschinger, 2012; Wang et al., 2014; Leroy et al., 2015; Mehmood et al., 2016). al., 2016). Conceptually, the effect of authentic leadership on task performance is not straightforward if you look at the study of Avolio et al. (2004), Ilies et al (2005), and Hoch et al. (2016). The concept developed by the those scholars is in line with Bandura's (2001) view that the stimulus from the leader's behavior cannot directly produce a response in the form of employee task performance. According to Hoch et al. (2016), the psychological mechanism that explains the process of leader behavior in producing outputs must contain relational perceptions, attitudes, and employee behaviors that are arranged in a coherent manner. Therefore, this study tries to reveal the variables that should be generated by authentic leadership behavior before finally creating task performance.

Responding to the issues above, this study makes the proposition that the role of authentic leadership behavior has an integrative mechanism that includes relational perceptions in the form of trust in the leader, work attitudes in the form of work engagement, and task performance as outputs.

Another issue that this research pays attention to is the empirical context of authentic leadership. Research contexts in western regions such as the U.S., Canada, Spain, and Belgium (Chiaburu et al., 2013; Laschinger and Fida, 2014; Leroy et al., 2012; Valsania et al., 2012) dominate empirical studies of authentic leadership. Meanwhile, a study by a group of Southeast Asian countries has been carried out on Malaysia, Iran and India. (Cerne and Penger, 2014; Hassan and Ahmed, 2011; Rahimnia and Sharifirad, 2014). This is supported by the results of a meta-analysis conducted by Banks et al. (2016) and Gardner et al. (2011) which shows that empirical studies conducted in the Southeast Asian region are still limited. Therefore, authentic leadership research in Southeast Asia's regional context in, especially Indonesia, still needs empirical support. 
In addition, Banks et al. (2016), through their study show that the distribution of research on authentic leadership focused on business-oriented organizations. Research on these business organizations has been carried out in various sectors including service companies (Leroy et al., 2012; Peus et al., 2012; Leroy et al., 2015; Hsieh and Wang, 2015), shipping and logistics (Nielsen, 2013; Wang et al., 2014), construction (Ozkan and Ceylan, 2012), manufacturing (Peus et al., 2012; Hsieh and Wang, 2015) and retail (Rego et al., 2012). On the other hand, authentic leadership research on non-profit organizations has been carried out in military organizations with a sample of navy and army personnel (Borgersen et al., 2014), health organizations with a sample of various health workers (Laschinger and Fida, 2014) and educational organizations with a sample of teachers (Roncesvalles and Sevilla, 2015). This study proposes governmental organizations as the context for examining the mechanism of the role of authentic leadership. Providing this enrichment of the sectoral context of authentic leadership studies is part of the contribution this research makes to the literature.

\section{Literature Review and Development of the Hypotheses}

\subsection{The Effect of Authentic Leadership on Trust in Leaders}

Leaders need to gain the trust of their employees because trust can bind employees to their leaders (Wong and Cummings, 2009). Employees will not develop trust in their leader, unless they believe that the leader is capable of fulfilling their leadership role. This belief comes from the competence, credibility and integrity of the leader and these attributes are the basis of trust (Hsieh and Wang, 2015).

Authentic leadership is a pattern of behavior on the part of a leader that promotes self-awareness, internalization of moral perspectives, balanced information processing, and transparent relationships with employees. These characteristics cause authentic leadership to be seen by employees as a leadership model that has attractiveness and credibility (Avolio et al., 2004). This statement is reinforced by Weischer et al. (2013) who state that authentic leaders are social actors who are able to provide positive role modeling. It is predicted that this leads to authentic leadership producing positive outcomes in the form of trust in the leader. This influence can be explained using social cognitive theory which emphasizes the existence of observational learning or the learning process by observing (Bandura, 2001). The employee learning process in this context can occur by paying attention to a model, namely an authentic leader. Observation of the model is not only for imitating or repeating the behavior but also involves cognitive processes which can then influence perception. This positive perception of the leader will strengthen the employee's belief that the leader can be trusted. This can be caused by several factors.

First, authentic leaders have good knowledge about themselves (Avolio et al., 2004). Second, authentic leaders are able to internalize a moral perspective by acting in accordance with fundamental values and beliefs in the work environment (Walumbwa et al., 2008). Third, authentic leadership has the advantage of involving employees in making decisions related to work (Walumbwa et al., 2008; Hsieh and Wang, 2015). Finally, authentic leaders have the ability to develop realistic and honest relationships when interacting with their employees (Ilies et al., 2005; Waischer et al., 2013). This ability makes employees feel confident that the 
leader can be trusted to manage the organization well (Hassan and Ahmed, 2011). Based on this logical explanation and the results of empirical studies, the first hypothesis is formulated as follows:

\section{Hypothesis 1: Authentic leadership has a positive effect on trust in leaders.}

\subsection{The Effect of Trust in Leaders on Work Engagement}

Work engagement is reflected in employees who are fully committed to their work by focusing their energy, thoughts and resources on their work (Schaufeli et al., 2002). According to Chughtai and Buckley (2009), one of the important predictors in increasing work engagement is trust in the leader. In accordance with the perspective of social cognitive theory, the person factors pertaining to the individual - which include perceptions, beliefs, expectations, attitudes and knowledge - can interact with each other (Bandura, 2001). In this context, employee confidence, as seen in their trust in their leaders, will encourage them to exhibit a positive attitude in the form of work engagement. This belief fosters employees confidence in their leader being able to help them when faced with work-related difficulties (Hassan and Ahmed, 2011). Furthermore, that trust will make employees willing to devote time and energy to get their work done.

According to Hsieh and Wang (2015), increased trust in leaders aligns with increased motivation and work commitment which makes employees more engaged with their work. This statement is supported by Tabak and Hendy (2016) who provided evidence that trust in leaders can create positive emotions that facilitate employees to be involved and engaged with their work. Thus, employees who trust the leader will be more enthusiastic, dedicated and absorbed when working (Xanthopoulou et al. 2008). On the other hand, when employees do not trust the leader, they will act irresponsibly toward their work. Based on these theories and empirical findings, the second hypothesis is formulated, namely:

\section{Hypothesis 2: Trust in the leader has a positive effect on work engagement.}

\subsection{Effect of Work Engagement on Task Performance}

A decline in task performance is one of the important problems both theoretically and practically in organizational research (Shantz et al., 2013). This is because good task performance is an aspect employee behavior that is needed to achieve organizational effectiveness. Work engagement is a positive work attitude characterized by energy, dedication, absorption or focus on work that is considered to have a central role in generating performance. Engaged employees will devote physical, cognitive and affective resources to generate greater effort when facing difficulties, thereby causing better task performance (Bakker et al., 2012). This is in line with the thinking of Bandura (2001) who states that personal factors in the form of attitudes can determine the quality of behavior in the learning process. In the work context, personal factors in the form of work engagement will affect task performance (behavior).

Bakker and Demerouti (2008) state that there are several reasons why engaged employees perform tasks better than non-engaged employees. First, employees who are engaged with 
their work will experience positive emotions reflected in their happiness, joy and enthusiasm when working. Second, employees who are engaged in their work are believed to have good physical and psychological health. Third, employees who are engaged with their work will have the ability to mobilize resources properly. They will be able to share the allocation of resources they have for their work properly. Engaged employees can also pass on their engagement to others. Based on this theory and empirical findings, the third hypothesis is formulated, namely:

\section{Hypothesis 3: Work engagement has a positive effect on task performance.}

\subsection{Coworker Support Moderates the Effect of Work Engagement on Task Performance}

Support from colleagues is believed to be one of the potential sources that can reduce stress levels and improve employee performance (Beehr et al., 2000). Coworker support can be promoted through the presence of emotional and instrumental support. According to Tabak and Hendy (2016) the support of colleagues plays an important role in strengthening the influence of personal conditions on employee work behavior. According to Alder et al. (2012), employees who feel that their co-workers support them will have more commitment and make more effort to complete their tasks. Thus, employees who have work engagement are characterized by their willingness to allocate their physical, cognitive and emotional energy (person or individual factors) and feel support from co-workers (situational factors) which make them strive and be more committed to completing their work, which means they are increasingly able to perform their tasks well. It can be said that, with the support of colleagues, the effect of work engagement on task performance becomes stronger. This is in line with social cognitive theory that person factors reinforced by environmental factors will produce better positive behavior in the work process.

The role of colleagues cannot be ignored in terms of the provision of positive feedback: for example, the performance of the sales force, especially when experiencing pressure over decision making (Liaw et al., 2010). The support from these co-workers will make salespeople more confident which is useful in maximizing their job performance. Furthermore, Amarneh et al. (2010) state that, if nurses have a tough task related to the quality of patient care, they need communication with colleagues to complete their work. Thus Al-Rub (2004) states that employees who are supported by co-workers will work better than employees who do not get support. In addition, with the support of colleagues, employees will be comfortable with asking colleagues to help complete the task. Based on this, the researchers have formulated a fourth hypothesis as follows:

\section{Hypothesis 4: Coworker support moderates the effect of work engagement on task performance.}

\section{Method}

\subsection{Population and Sample}

The population in this study are civil servants within the organizational scope of the Provincial Government. The respondents in this study amounted to 357. The determination of 
the number of samples is derived from the rules of thumb proposed by Hair et al. (2014) which says that, in determining the sample size, it is recommended that a minimum of 300 samples are used when using SEM multivariate analysis and when the number of variables is less than seven. In line with this, the number of respondents meets these requirements. Meanwhile, determining the location of the sample in the Provincial Government organization aims to provide variations in the distribution in a sectoral context (Banks et al., 2016).

This study uses purposive sampling techniques (non-probability sampling), in other words it determines respondents based on certain criteria (Cooper \& Schindler, 2014). The criterion based on the needs of this study have been determined as follows: the period of time the respondent have worked in the position with the same leader is at least two years. This is to ensure that the respondents are familiar with their respective superiors. Two years is a fairly well-established period for a respondent to assess their leader and work environment.

\subsection{Measurement}

Authentic leadership has been measured using 16 items (statements) from the Authentic Leadership Questionnaire (ALQ). The ALQ was developed by Walumbwa et al. (2008) based on four characteristics of authentic leadership, namely self-awareness, internalization of moral perspectives, balanced information processing, and relational transparency. Examples of statements are: "My superior is able to demonstrate his abilities to others"; "My superior is able to analyze relevant data before making decisions"; and "My superior has the courage to admit mistakes that have been made."

The measurement of trust in leaders uses a ten items (statements) developed by Yang and Mossholder (2010). Examples of statements are: "I believe that my superior can be relied on in terms of fulfilling his responsibilities"; "My superior keeps to the commitments he has made"; and "I feel confident that I can communicate personal feelings to my superior."

The measurement of work engagement uses the nine items of the Utrecht Work Engagment Scale (UWES). The UWES was developed by Schaufeli and Bakker (2003). Examples of statements are: "I feel excited about going to work"; "I feel proud to do my job"; and "I feel happy when I can work diligently."

The measurement of the performance of tasks uses seven items (statements) developed by Williams and Anderson (1991). Examples of statements are: "I complete the tasks assigned to me"; "I fulfill my responsibilities according to the tasks listed in the job description"; and "I follow the formal standards of performance requirements in carrying out my duties."

The measurement of peer support in this study uses a 14 items (statements) developed by Settoon and Mossholder (2002) and redeveloped by Tews et al. (2013). Examples of statements are: "Coworkers try to make me feel welcome in the work group"; "Coworkers provide assistance when I have a heavy workload"; and "Coworkers provide assistance when I am late in completing work". 


\section{1) Macrothink}

\section{Results and Discussion}

The multivariate data analysis used in this study is Structural Equation Modeling-Partial Least Square (SEM-PLS). Statistical analysis using SEM-PLS consists of two stages, namely the measurement model and the structural model.

\subsection{Measurement Model}

With the measurement model there are tests of validity and reliability. Instrument validity consists of convergent and discriminant validity. According to the results of the measurement model test, only forty-eight statements can be used for the next data analysis process. Meanwhile, eight statements whose loading factor value is less than 0.7 cannot be used. This is in accordance with Hair et al. (2014) who posit that a statement is said to have convergent validity if the loading factor value is greater than 0.7 . The discriminant validity of this study is quite good because the AVE root value of each variable is greater than 0.5 and greater than the correlation between variables. More detailed discriminant validity results can be seen in Table 01 .

Tabel 01. Result of Discriminant Validity Test

\begin{tabular}{lccccc}
\hline Variable & AL & TL & WE & TP & SC \\
\hline AL & $\mathbf{( 0 . 7 6 9 )}$ & 0.243 & 0.431 & 0.249 & 0.084 \\
TL & 0.243 & $\mathbf{( 0 . 7 4 1 )}$ & 0.430 & 0.463 & 0.042 \\
WE & 0.431 & 0.430 & $\mathbf{( 0 . 7 4 7 )}$ & 0.561 & 0.165 \\
TP & 0.249 & 0.463 & 0.561 & $\mathbf{( 0 . 8 0 9 )}$ & 0.128 \\
SC & 0.084 & 0.103 & 0.165 & 0.128 & $\mathbf{( 0 . 7 3 3 )}$
\end{tabular}

Note: Square roots of average variances extracted (AVE's) shown on diagonal

Key: AL: Authentic Leadership; TL: Trust in Leaders; WE: Work Engagement; TP: Task Performance

SC: Support of Co-workers

Table 02. The Result of Reliability Test

\begin{tabular}{lccc}
\hline \multicolumn{1}{c}{ Variable } & $\begin{array}{c}\text { Cronbach's } \\
\text { Alpha }\end{array}$ & $\begin{array}{c}\text { Composite } \\
\text { Reliability }\end{array}$ & Ket \\
\hline Authentic Leadership & 0.950 & 0.957 & Reliable \\
Trust in Leadership & 0.895 & 0.918 & Reliable \\
Work Engagement & 0.879 & 0.910 & Reliable \\
Performance & 0.911 & 0.930 & Reliable \\
Support of Co-workers & 0.920 & 0.935 & Reliable \\
\hline
\end{tabular}

Table 02 shows that all the variables used in the study confirmed as being reliable. Reliability for each research variable is very good, because the Cronbach Alpha and Composite Reliability values are above 0.8 . 


\subsection{Statistic Descriptive}

Table 03. The Result of Statistic Descriptive

\begin{tabular}{lccccccc}
\hline \multicolumn{1}{c}{ Variable } & N & Mean & $\begin{array}{c}\text { Deviation } \\
\text { Standard }\end{array}$ & AL & TL & WE & SC \\
\hline Authentic Leadership (AL) & 357 & 3,79 & 0,42 & & & & \\
Trust in Leadership (TL) & 357 & 3,93 & 0,43 & $0,42^{\cdots \cdots}$ & & & \\
Work Engagement (WE) & 357 & 3,91 & 0,41 & $0,39^{* *}$ & $0,64^{* *}$ & & \\
Task Performance (TP) & 357 & 3,74 & 0,46 & $0,40^{\cdots \cdots}$ & $0,55^{\cdots \cdots}$ & $0,65^{\cdots \cdots}$ & \\
Support of Co-workers & 357 & 3,91 & 0,41 & $0,31^{\cdots \cdots}$ & $0,47^{\cdots \cdots}$ & $0,45^{\cdots \cdots}$ & $0,58^{\cdots \cdots}$ \\
(SC) & & & & & & & \\
\hline
\end{tabular}

Table 03 represents that all the variables used in the study confirmed as being correlated and significant.

\subsection{Structural Model}

The measurement model is used to test the research hypothesis. Figure 1 shows the structural model of this study.

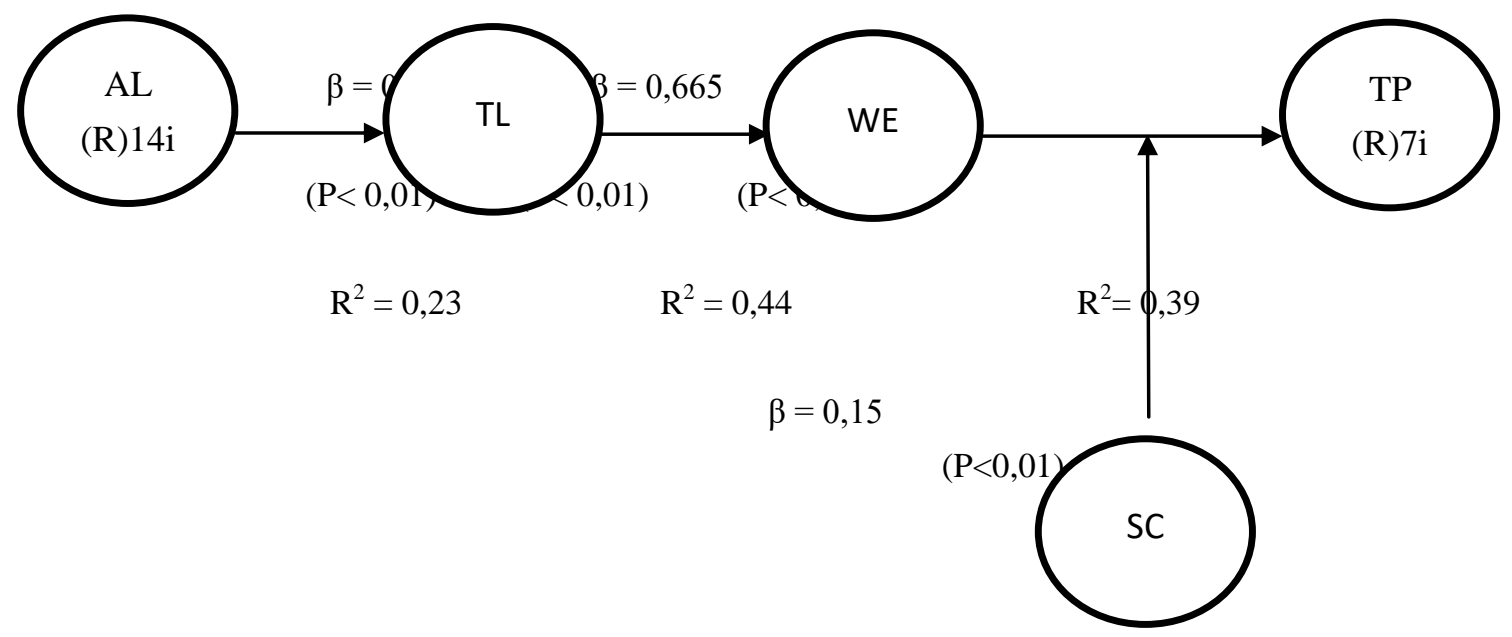

Figure 01. The Structural Model of this Study

Table 04. The Result of Hypothesis Testing

\begin{tabular}{lcccccc}
\hline \multicolumn{1}{c}{ Path } & & Coefficient & $\boldsymbol{p}$ Value & $\boldsymbol{R}^{2}$ & $\boldsymbol{Q}^{2}$ & Effect Size \\
\hline $\begin{array}{l}\text { Authentic Leadership (AL) } \\
\text { Trust in Leadership (TL) }\end{array}$ & & 0,48 & $p<0,001$ & 0,23 & 0,232 & 0,23 \\
$\begin{array}{l}\text { Trust in Leadership } \\
\text { Work Engagement (WE) }\end{array}$ & & 0,665 & $p<0,001$ & 0,44 & 0,445 & 0,442 \\
$\begin{array}{l}\text { Work Engagement } \longrightarrow \\
\text { Task Performance (TP) }\end{array}$ & & 0,63 & $p<0,001$ & 0,39 & 0,424 & 0,412 \\
$\begin{array}{l}\text { Work Engagement * Support of } \\
\text { Co-workers (SC) }\end{array}$ & & 0,15 & $p<0,001$ & & & 0,012 \\
Fit Indicator & & & & & & \\
APC & & 0,481 & $p<0,001$ & & & \\
ARS & 0,353 & $p<0,001$ & & & \\
AVIF & 1,037 & $p<0,001$ & & & \\
\hline
\end{tabular}


Based on the results of structural model testing and hypotheses testing, hypothesis $\mathbf{1}$, which states that authentic leadership has a positive effect on employee trust in leaders, is supported $\left(\beta=0.48 ; \mathrm{p}<0.01 ; \mathrm{R}^{2}=0.23\right)$. These results show that the more the leader shows authentic behavior, the greater the employee's trust in him or her. Hypothesis 2, which states that employee trust has a positive effect on work engagement, is supported $(\beta=0.665 ; p=$ $\left.0.01 ; \mathrm{R}^{2}=0.44\right)$. This shows that the more employees have greater trust in the leader, the the more their work engagement will increase.

Hypothesis 3, namely that work engagement has a positive effect on task performance, is also supported $\left(\beta=0.63 ; \mathrm{p}<0.01 ; \mathrm{R}^{2}=0.39\right)$. This means that when the employee's work engagement is greater, it will correspond to an increase in task performance. Meanwhile, hypothesis 4 , which tests the moderating variable, in this case the support of colleagues, also shows a positive and significant coefficient value at the $1 \%$ level. This means that with the support of colleagues, the effect of work engagement on performance will also be stronger. Furthermore, hypothesis 4, which states that coworker support moderates the effect of work engagement on task performance, is supported.

\subsection{Discussion}

The result of testing hypothesis 1, that authentic leadership behavior has a positive effect on employee trust in leaders, is in accordance with the perspective of social cognitive theory. The theory states that leaders have the credibility to play a modeling role that is able to have an impact on employees' perceptions, beliefs, attitudes and behavior (Bandura, 2001). Authentic leadership is a manifestation of organizational effective-ness in building employee trust (Wong et al., 2010).

Employee trust in leaders is also reported to have a positive effect on work engagement. This results strengthens the basic assumptions of social cognitive theory which state that personal factors such as beliefs, expectations, attitudes and knowledge will influence each other (Bandura, 2001). According to Hassan and Ahmed (2011), the climate of trust shown by employees toward their leaders is important capital for growing employee engagement in their work.

Work engagement has a positive effect on employee job performance. This result strengthens the view of social cognitive theory which suggests that personal factors such as work engagement can encourage improved employee behavior in the form of the performance of their tasks. The increase in employee work engagement is accompanied by an increase in the intensity of employee behavior in carrying out tasks for a longer period of time (Xanthopoulou et al., 2008).

Support from colleagues is reported to moderate the positive effect of work engagement on employee job performance. This finding confirms the concept of social cognitive theory, says that positive behavior can be influenced by individual personal factors which are reinforced by factors originating from the environment (Bandura, 2001). Employees who feel supported and motivated by their co-workers are more loyal and committed to their work (Bowling et al., 2004). Thus, with the support of colleagues, the effect of work engagement on task 
performance becomes stronger (Al-Rub, 2004).

\subsection{Research Contribution}

The theoretical contribution of this study is that it provides a new perspective on the comprehensive mechanism of the role of authentic leadership behavior as it affects employee task performance with a social cognitive theory approach. The results of this study also enrich the literature on the role of authentic leadership, not only by focusing on the positive attitude of employees, but also by being able to influence the achievement of positive employee performance. In addition, the results of this research also add to the empirical evidence regarding the positive influence of authentic leadership behavior on employee confidence in leaders in Indonesia in the context of government organizations. Meanwhile, this research also makes some practical contributions. First, organizations should focus on authentic leadership behavioral characteristics when selecting prospective leaders. Second, leaders need to use language that is easy to understand and communicate more transparently because this leads to positive relational aspects and increases the trust that members of organizations have in their leaders. Third, organizations need to manage good interpersonal relationships among members so as to create a mutually supportive work environment.

\section{Suggestions}

Although this research has been well planned, there are still some limitations that need to be improved upon in future research. First, the findings of this study are more focused on the local government organizational environment in an area. The findings of this study may not be able to represent government organizations in general. It is hoped that future research would be able to use research locations in government organizations from other regions, so that studies could obtain a comprehensive picture. Second, this study focuses on examining the psychological mechanisms of authentic leadership behavior in affecting employee job performance. Therefore, further research is expected to be able to describe the psychological mechanisms of authentic leadership behavior in producing outputs in other forms of behavior such as organizational citizenship behavior, voice behavior, and help behavior which also contribute to organizational work outcomes (Valsania et al., 2012; Wong et al. ., 2010; Wong and Cummings, 2009).

Third, this research focuses on positive outcomes. Further research could test the effectiveness of authentic leadership in minimizing negative outcomes in the form of turnover intention or counterproductive work behavior (Nielsen, 2013). Fourth, this research only raises the issue of the output of authentic leadership. As a relatively new construct, authentic leadership still requires deeper exploration regarding its antecedents. Therefore, future research could focus on raising theoretical issues, especially the antecedents of authentic leadership such as psychological ownership (Jensen and Luthan, 2006).

\section{References}

Abid, T., Altaf, M., Yousaf, U., \& Bagram, M. (2012). Entrepreneur as an authentic leader: A study of small and medium sized enterprises in Pakistan. Management Science Letters, 2, 2355-2360. https://doi.org/10.5267/j.msl.2012.08.007 
Alder, G. S., McAllister, D., \& Chase, J. (2012). We get by with a little help from our friends: exploring of perceived coworker support on employee burnout and job attitudes. Advances in Business Research, 3(1), 1-11.

Al-Rub, R. F. A. (2004). Job stress, job performance, and social support among hospital $\begin{array}{llllll}\text { nurses. } & \text { Journal } & \text { of } & \text { Nursing } & \text { Scholarship, } & 36,\end{array}$ https://doi.org/10.1111/j.1547-5069.2004.04016.x

Amarneh, B. H., Al-Rub, R. F. A., \& Al-Rub, N. F. A. (2010). Coworkers' support and job performance among nurses in Jordanian hospitals. Journal of Research in Nursing, 15, 391-401. https://doi.org/10.1177/1744987109347134

Arda, O. A., Aslan, T., \& dan Alpkan, L. (2016). Review of pratical implication in authentic leadership studies. Social and Behavoiral Science, 229, 246-252. https://doi.org/10.1016/j.sbspro.2016.07.135

Avolio, B. J., \& Gardner, W. L. (2005). Authentic leadership development: getting to the root of positive forms of leadership. The Leadership Quarterly, 16, 315-338. https://doi.org/10.1016/j.leaqua.2005.03.001

Avolio, B. J., Gardner, W. L., Luthans, F., \& May, D. R. (2004). Unlocking the mask: a look at the process by which authentic leaders impact follower attitudes and behavior. The Leadership Quarterly, 15(6), 801-823. https://doi.org/10.1016/j.leaqua.2004.09.003

Azanza, G., Moriano, J. A., \& Molero, F. (2013). Authentic leadership and organizational culture as drivers of employees' job satisfaction. Journal of Work and Organizational Psychology, 29, 45-50. https://doi.org/10.5093/tr2013a7

Bakker, A. B., \& Demerouti, E. (2008). Towards a model of work engagement. Career Development International, 13(3), 209-223. https://doi.org/10.1108/13620430810870476

Bakker, A. B, Demerouti, E., \& Brummelhuis, L. L. (2012). Work engagement, performance, and active learning: The role of conscientiousness. Journal of Vocational Behavior, 80, 555-564. https://doi.org/10.1016/j.jvb.2011.08.008

Bamford, M., Wong, C. A., \& Laschinger, H. (2013). The influence of authentic leadership and areas on work-life on work engagement of registered nurses. Journal of Nursing Management, 21, 529-540. https://doi.org/10.1111/j.1365-2834.2012.01399.x

Bandura A. (2001). Social cognitive theory: An agentic perspective. Annual Review of Psychology, 52, 1-26. https://doi.org/10.1146/annurev.psych.52.1.1

Banks, G. C., McCauley, K. D., Gardner, W. L., \& Guler, C. E. (2016). A meta-analytic review of authentic and transformational leadership: A test for redundancy. The Leadership Quarterly, 27, 634-652. https://doi.org/10.1016/j.leaqua.2016.02.006

Beehr, T. A., Jex, S. M., Stacy, B. A., \& Murray, M. A. (2000). Work stressors and coworker support as predictors of individualal strain and job performance. Journal of Organizational Behavior, 
https://doi.org/10.1002/(SICI)1099-1379(200006)21:4<391::AID-JOB15>3.0.CO;2-9

Borgersen, H. C., Hystad, S. W., Larsson, G., \& Eid, J. (2014). Authentic leadership and safety climate among seafarers. Journal of Leadership \& Organisational Studies, 21, 394-402. https://doi.org/10.1177/1548051813499612

Bowling, N. A., Beehr, T. A., Johnson, A. L., Semmer, N. K., Hendricks, E. A., \& dan Webster, H. A. (2004). Explaining po-tential antecedents of workplace social support: reciprocity or attractiveness? Journal of Occupational Health Psychology, 9, 339-350. https://doi.org/10.1037/1076-8998.9.4.339

Cai, Z., Parker, S. K., Chen, Z., \& Lam, W. (2019). "How does the social context fuel the proactive fire? A multi-level review and theoretical synthesis." Journal of organizational behavior, 40, 209-320. https://doi.org/10.1002/job.2347

Černe, M., \& Penger, S. (2014). Authentic leadership, employees' job satisfaction, and work engagement: a hierarchical linear modelling approach. Economic Research-Ekonomska Istraživanja, 27(1), 508-526. https://doi.org/10.1080/1331677X.2014.974340

Chiaburu, D. S., Lorinkova, N. M., \& Van Dyne, L. (2013). Employees' social context and change-oriented citizenship: a meta-analysis of leader, coworker, and organizational influences. Group dan Organization Management, 38, 291-333. https://doi.org/10.1177/1059601113476736

Chughtai, A., A., \& Buckley, F. (2009). Lingking trust in the principal to school outcome the mediating role of organizational identification and work engagement. International Journal of Educational Management, 23(7), 574-589. https://doi.org/10.1108/09513540910990816

Cooper, D. R., dan Schindler, P. S. (2014) Bussiness Research Methods, 12th ed. New York: McGraw-Hill.

Gardner,W. L., Cogliser, C. C., Davis, K. M., \& Dickens, M. P. (2011). Authentic leadership: a review of the literature and research agenda. The Leadership Quarterly, 22, 1120-1145. https://doi.org/10.1016/j.leaqua.2011.09.007

Guerrero, S., Lapalme, M. E., \& Seguin, M. (2014). Board chair authentic leadership and nonexecutives' motivation and commitment. Journal of Leadership and Organizational Studies, 22(1), 88-101. https://doi.org/10.1177/1548051814531825

Hair, F. J., Black, C. W., Babin, J. B., \& Anderson, E. R. (2014). Multivariate Data Analysis. London: Pearson Education Limited.

Hassan, A., \& Ahmed, F. (2011). Authentic leadership, trust and work engagement. International Journal of Social, Human Science and Engineering, 5(8), 1-7.

Hoch, J. E., Bommer, H. W., Dulebohn, J. H., \& Wu, D. (2016). Do ethical, authentic, and servant leadership explain variance above and beyond transformasional leadership? a meta-analysis. Journal of Management, 20(10), 1-29.

Hsieh, Chia-Chun and Wang, Dan-Shang. (2015). Does supervisor-perceived authentic 
leadership influence employee work engagement through employee-perceived authentic leadership and employee trust? The International Journal of Human Resource Management, 26(18), 2329-2348. https://doi.org/10.1080/09585192.2015.1025234

Ilies, R., Morgeson, F. P., \& Nahrgang, J. D. (2005). Authentic leadership and eudaemonic well-being: understanding leader-follower outcomes. The Leadership Quarterly, 16, 373-394. https://doi.org/10.1016/j.leaqua.2005.03.002

Jensen, S. M., \& Luthans, F. (2006). Entrepreneurs as authentic leaders: Impact on employees' attitudes. Leadership and Organizational Development Journal, 27, 646-666. https://doi.org/10.1108/01437730610709273

Laschinger, H., \& dan Fida, R. (2014). A time-lagged analysis of the effect of authentic leadership on workplace bullying, burnout, and occupational turnover intentions. European Journal of Work and Organizational Psychology, 23, 739-753. https://doi.org/10.1080/1359432X.2013.804646

Liaw, Y., Chi, N., \& Chuang, A. (2010). Examining the mechanisms linking transformational leadership, employee customer orientation, and service performance: the mediating roles of perceived supervisor and coworker support. Journal of Business and Psychology, 25(3), 477-492. https://doi.org/10.1007/s10869-009-9145-X

Leroy, H., Anseel, F., Gardner,W. L., \& Sels, L. (2012). Authentic leadership, authentic followership, basic need satisfaction, and work role performance: A cross-level study. Journal of Management, 41(6), 1677-1697. https://doi.org/10.1177/0149206312457822

Leroy, H., Palanski, M. E., \& Simons, T. (2015). Authentic leadership and behavioral integrity as drivers of follower commitment and performance. Journal of Business Ethics, 107, 255-264. https://doi.org/10.1007/s10551-011-1036-1

Mehmood, Q., Hamstra, M. R. W., Nawab, S., \& Vriend, T. (2016). Authentic leadership and follower's in-role and extra-role performance: The mediating role of follower's lerning goal orientation. Journal of Occupational and Organization, 89, 877-883. https://doi.org/10.1111/joop.12153

Miao, C., Humphrey, R. H., \& Qian, S. (2018). Emotional intelligence and authentic leadership: a meta-analysis. Leadership and Organization Development Journal, 39(5), 679-690. https://doi.org/10.1108/LODJ-02-2018-0066

Nielsen, M. B. (2013). Bullying in work groups: The impact of leadership. Scandinavian Journal of Psychology, 54, 127-136. https://doi.org/10.1111/sjop.12011

Ozkan, S., \& Ceylan, A. (2012). Multi-level analysis of authentic leadership froma Turkish construction engineers perspective. South East European Journal of Economics \& Business, 101-114. https://doi.org/10.2478/v10033-012-0018-2

Peterson, S. J., Walumbwa, F. O., Avolio, B., \& Hannah, S. T. (2012). The relationship between authentic leadership and follower job performance: The mediating role of follower positivity in extreme contexts. The Leadership Quarterly, 23, 502-516. 
https://doi.org/10.1016/j.leaqua.2011.12.004

Peus, C., Wesche, J., S., Braun, S., \& Frey D. (2012). Authentic Leadership: an empirical test of its antecedents, consequences, and mediating mechanisms. Journal Business Ethics, 107, 331-348. https://doi.org/10.1007/s10551-011-1042-3

Rahimnia, F., \& Sharifirad, M. S. (2014). Authentic leadership and employee well-being: the mediating role of attachment insecurity. Journal Business Ethics. https://doi.org/10.1007/s10551-014-2318-1

Ratanjee, V., \& Wu, M. (2013). Why Indonesia needs authentic leadership. available at http://www.gallup.com/businessjournal/164378/why-indonesia-needs-authentic-leaders.

Accessed on 20th January 2017.

Rego, A., Sousa, F.,Marques, C., \& Cunha,M. P. (2012). Authentic leadership promoting employees' psychological capital and creativity. Journal of Business Research, 65, 429-437. https://doi.org/10.1016/j.jbusres.2011.10.003

Roncesvalles, M. C. T., \& Sevilla, A. V. (2015). The impact of authentic leadership on subordinates' trust and work performance in educational organization: a structural equation modeling. Journal of Educational and Management Studies, 5(1), 69-79.

Schaufeli, W. B., \& Bakker, A. B. (2003). Utrecht Work Engagement Scale: preliminary manual. Department of Psychology, Utrecht University, The Netherlands. https://doi.org/10.1037/t76451-000

Schaufeli, W. B., Salanova, M., Gonzalez-Roma, V., \& Bakker, A. B. (2002). The measurement of engagement and burnout: a two sample confirmatory factor analytic approach. Journal of Happiness Studies, 3, 71-92. https://doi.org/10.1023/A:1015630930326

Settoon, R. P., \& Mossholder, K. W. (2002). Relationship quality and relationship context as antecedents of person- and task-focused interpersonal citizenship behavior. Journal of Applied Psychology, 87, 255-267. https://doi.org/10.1037/0021-9010.87.2.255

Shantz, A., Alfes, K., Truss, C., \& Soane, E. (2013). The role of employee engagement in the relationship between job design and task performance, citizenship, and deviant behaviours. The International Journal of Human Resouece Management, 24(13), 2608-2627. https://doi.org/10.1080/09585192.2012.744334

Tabak, F., \& Hendy, N., T. (2016). Work engagement: trust as a mediator of the impact of organizational job embeddedness and perceived organizational support. Organizational Management Journal, 13(1), 23-31. https://doi.org/10.1080/15416518.2015.1116968

Tews, M. J., Michel, J. W., \& Ellingson, J. E. (2013). The impact of coworker support on employee turnover in the hospitality industry. Group dan Organization Management, 38, 630-653. https://doi.org/10.1177/1059601113503039

Valsania, S. E., Leon, J. A.M., Alonso, F.M., \& Cantisano, G. T. (2012). Authentic leadership and its effect on employees' organizational citizenship behaviors. Psicothema, 24, 561-566. 


\section{Macrothink}

International Journal of Human Resource Studies

ISSN 2162-3058 2022, Vol. 12, No. 1

Walumbwa, F. O., Avolio, B. J., Gardner, W. L., Wernsing, T. S., \& Peterson, S. J. (2008). Authentic leadership: development and validation of a theory-based measure. Journal of Management, 34, 89-126. https://doi.org/10.1177/0149206307308913

Wang, H., Sui, Y., Luthans, F., Wang, D., \& Wu, A. Y. (2014). Impact of authentic leadership on performance: role of followers' positive psychological capital and relational processes. Journal of Organizational Behavior, 35, 5-21. https://doi.org/10.1002/job.1850

Weischer, A. E., Weibler, J., \& Peterson, M. (2013). To thine own self be true: the effects of enactment and life storytelling on perceived leader authenticity. The Leadership Quarterly, 24, 477-495. https://doi.org/10.1016/j.leaqua.2013.03.003

Wong, C. A., \& Cummings, G. G. (2009). The influence of authentic leadership behaviors on trust and work outcomes of health care staff. Journal of Leadership Studies, 3(2), 6-23. https://doi.org/10.1002/j1s.20104

Wong, C. A., Laschinger, H. K., \& Cummings, G. G. (2010). Authentic leadership and nurses' voice behavior and perceptions of care quality. Journal of Nursing Management, 18, 889-900. https://doi.org/10.1111/j.1365-2834.2010.01113.x

Wong, C. A., \& Laschinger, H. (2012). Authentic leadership, performance, and job satisfaction: the mediating role of empowerment. Journal of Advanced Nursing, 69, 947-959. https://doi.org/10.1111/j.1365-2648.2012.06089.x

Xanthopoulou, D., Bakker, A. B., Heuven, E., Demerouti, E., \& Schaufeli, W. B. (2008). Working in the sky: A diary study on work engagement among flight attendants. Journal of Occupational Health Psychology, 13, 345-356. https://doi.org/10.1037/1076-8998.13.4.345

\section{Copyright Disclaimer}

Copyright for this article is retained by the author(s), with first publication rights granted to the journal.

This is an open-access article distributed under the terms and conditions of the Creative Commons Attribution license (http://creativecommons.org/licenses/by/4.0/). 